\title{
Costorage of Serotonin Binding Protein with Serotonin in the Rat CNS
}

\author{
A. L. Kirchgessner, M. D. Gershon, K. P. Liu, and H. Tamir \\ Department of Anatomy and Cell Biology, Columbia University College of Physicians and Surgeons, and the Division of \\ Neuroscience, New York State Psychiatric Institute, New York, New York 10032
}

Previous studies have identified two neurectoderm-specific serotonin binding proteins (SBP), one with an apparent $M_{r}$ of $45 \mathrm{kDa}$, and one of $56 \mathrm{kDa}$. The current experiments were undertaken to test the hypothesis that these proteins are specific components of serotonergic neurons. Since actin has been found to bind serotonin, the relationship of the 2 forms of SBP to actin was also investigated. Antisera against purified 45 and 56 kDa SBP were raised in rabbits and shown by analyses of immunoblots and differential absorption to be monospecific and not cross-reactive. Neither antiserum reacted with purified actin and none of 3 different anti-actin sera reacted with purified 45 or $56 \mathrm{kDa}$ SBP. The antisera to 45 and $56 \mathrm{kDa}$ were used for immunocytochemical localization of the proteins, which was compared to that of serotonin. SBP immunoreactivity was found in rat brain and spinal cord; however, no significant differences were observed in the pattern of distribution of 45 and 56 kDa SBP-immunoreactive structures. Immunostaining of neuronal perikarya by either SBP antiserum required pretreatment of animals with colchicine. The distribution of neurons and terminals labeled by each antiserum to SBP was similar to that of neurons and terminals labeled by anti-5-HT sera. SBP-immunoreactive neuronal perikarya were present in the nuclei raphe dorsalis, raphe centralis superior, raphe medianus, raphe magnus, raphe obscurus, raphe pallidus, dorsal to the medial lemniscus in the region of the B9 cell group, near the interpeduncular nucleus, in the area postrema, the pars compacta of the substantia nigra, the dorsomedial nucleus of the hypothalamus, and the arcuate nucleus. SBP-immunoreactive fibers and terminals were present in many additional areas of the brain, as well as the spinal cord, where they paralleled those that were immunostained with antlbodies to 5-HT. When double-immunostaining was used, serotonin and 45 and 56 kDa SBP immunoreactivities were found to be colocalized in both the brain and spinal cord. Cells and fibers found to be stained by one immunoreagent were also stained by the others; therefore, serotonergic neurons of the CNS probably contain both 45 and $56 \mathrm{kDa}$ SBP. Moreover, it also seems likely that nonserotonergic neurons contain neither form of

\footnotetext{
Received Oct. 6, 1987; revised Dec. 11, 1987; accepted Jan. 25, 1988.

We wish to thank Ms. S. C. Hsiung and Dr. Pei Ying Yu for their technical assistance. This work was supported by NIH Grants NS 07062, NS 12969, NS 15547, and NIMH Grant 37575. A.L.K. was a fellow of the Pharmaceutical Manufacturers Association Foundation.

Correspondence should be addressed to Dr. Kirchgessner, Department of Anatomy and Cell Biology, Columbia University College of Physicians and Surgeons, 630 W. 168th St., New York, NY 10032.

Copyright (C) 1988 Society for Neuroscience $0270-6474 / 88 / 103879-12 \$ 02.00 / 0$
}

SBP. These data strongly suggest that SBP is an intrinsic and specific component of serotonergic neurons that can serve as a serotonergic marker.

Serotonin binding protein (SBP) was first found in the brain by Tamir and Huang (1974). Serotonin (5-HT) binds to SBP with high affinity $\left(K_{\mathrm{d}} \sim 0.1\right.$ and $\left.\sim 10 \mathrm{nM}\right)$ and specificity (Tamir et al., 1976; Liu et al., 1985). Previous studies have indicated that the distribution of SBP in the CNS closely parallels the distribution of 5-HT (Tamir et al., 1976; Tamir and Gershon, 1979). Lesions made in the midbrain nuclei of the median raphe in order to destroy serotonergic neuronal cell bodies decrease SBP activity in areas of the forebrain that receive serotonergic projections (Tamir and Kuhar, 1975). In addition, SBP accumulates above and is depleted below lesions of the thoracic spinal cord, which interrupt descending serotonergic pathways (Tamir and Gershon, 1979). The rate of rostral accumulation of SBP is compatible with its translocation by fast axonal transport to axon terminals. SBP has also been found outside the CNS. These peripheral sites include the enteric nervous system, where its appearance in ontogeny coincides with the development of enteric serotonergic neurons (Jonakait et al., 1977) and the 5-HTstoring parafollicular cells of the thyroid gland (Jonakait et al., 1979; Bernd et al., 1981; Barasch et al., 1987a, b). Both enteric serotonergic neurons (Rothman et al., 1986) and parafollicular cells (Polak et al., 1974) are neural crest derivatives. SBP is not found in 5-HT-storing cells, such as enterochromaffin cells (Gold et al., 1982), mast cells (Tamir et al., 1982), and platelets (Tamir et al., 1983, 1985) that are not derived from neurectoderm. These observations suggest, but do not prove, that SBP is an element of the neurectodermal type of 5-HT storage mechanism.

Considerable evidence supports the view that $\mathrm{SBP}$ is located in synaptic vesicles. In addition to its proximodistal movement by fast axonal transport, which is charactcristic of material in vesicles (Grafstein, 1977), SBP is enriched 4-fold over the supernatant in a synaptic vesicle fraction derived from lysed brain synaptosomes (Tamir and Gershon, 1979). The protein is released in a $\mathrm{Ca}^{2+}$-dependent manner, along with 5-HT, from stimulated enteric serotonergic neurons (Jonakait et al., 1979). Moreover, SBP has been shown by EM immunocytochemistry to be located in the secretory vesicles of parafollicular cells, which also contain 5-HT and calcitonin (Barasch et al., 1987b).

It has been proposed that SBP reduces the osmotic pressure within synaptic vesicles by binding 5-HT (Gershon et al., 1983). A similar mechanism may account for the reduction of osmotic pressure in the amine storage organelles of chromaffin cells and platelets. In these cells, ATP, which is present in high concentration in the granules, may form macromolecular complexes with biogenic amines (DaPrada and Pletscher, 1968; Berneis et 
al., 1969; Winkler and Westhead, 1980); however, 5-HT-containing vesicles from brain or thyroid appear to be very low in or totally devoid of AT'P (Tamir and Gershon, 1979; Richards, 1983; Barasch et al., 1987b). Thus, it is unlikely that intravesicular ATP functions in the storage of 5-HT. The role played by ATP in chromaffin or platelet granules may be played by SBP in neurectodermal 5-HT storage vesicles. The 5-HT binding properties of SBP make it suitable to play such a role. Binding of 5-HT by SBP is strong in media that, like intracellular fluid, contain little $\mathrm{Na}^{+}$and $\mathrm{Ca}^{2+}$, but is inhibited in the presence of concentrations of $\mathrm{Na}^{+}$and $\mathrm{Ca}^{2+}$ found in the extracellular space (Gershon and Tamir, 1981). 5-HT may thus be tightly bound to SBP within vesicles, but would dissociate following exposure of the 5-HT-SBP complex to the extracellular medium at the time of exocytosis.

There are 2 forms of SBP, one with an apparent $M_{\mathrm{r}}$ of $45 \mathrm{kDa}$ and one of $56 \mathrm{kDa}$ (Liu et al., 1985). When serotonergic neurons take up ${ }^{3} \mathrm{H}-5-\mathrm{HT}$, the labeled amine forms a complex with SBP in situ (Gershon ct al., 1983). ${ }^{3} \mathrm{H}-5-\mathrm{HT}$ is mainly taken up by axon terminals, and most of the ${ }^{3} \mathrm{H}-5-\mathrm{HT}$ that binds to SBP in situ is bound to the $45 \mathrm{kDa}$ form of the protein. On the other hand, when SBP is extracted from the brain, there is more 56 than $45 \mathrm{kDa}$ SBP. These observations suggest that the $45 \mathrm{kDa}$ form may predominate in axon terminals, while the $56 \mathrm{kDa}$ material may be most abundant in cell bodies. Such a distribution would be found if the $56 \mathrm{kDa}$ were the precursor of the $45 \mathrm{kDa}$ SBP. Preliminary studies have supported this hypothesis (Liu et al., 1985).

Despite the observations implying that SBP is an intrinsic component of serotonergic neurons, direct evidence demonstrating the colocalization of SBP and 5-HT in the same neurons has been lacking. The current study reports the generation and characterization of polyclonal antisera to the 45 and $56 \mathrm{kDa}$ forms of SBP and the immunocytochemical localization of these proteins in rat brain and spinal cord. The distribution of 45 and $56 \mathrm{kDa}$ SBP immunoreactivities was compared to that of 5-HT.

\section{Materials and Methods}

${ }^{3} H-5-H T$ binding assay. The assay for the measurement of SBP activity has been described previously (Tamir and Gershon, 1979). In brief, the protein, prepared from rat brain (Liu et al., 1985), was incubated for $15 \mathrm{~min}$ at $30^{\circ} \mathrm{C}$ with ${ }^{3} \mathrm{H}-5-\mathrm{HT}(0.2 \mu \mathrm{M})$ and $\mathrm{Fe}^{2+}(0.1 \mathrm{~mm})$. The incubation was carried out in the presence of potassium phosphate buffer $(0.02 \mathrm{M}, \mathrm{pH} 7.5)$. The resulting protein, $\mathrm{Fe}^{2+}-{ }^{3} \mathrm{H}-5-\mathrm{HT}$, was scparated from free 5 -HT by molecular sieve chromatography. Nonspecific binding, measured in the presence of a 1000 -fold excess of nonradioactive 5-HT, was subtracted from the total binding of ${ }^{3} \mathrm{H}-5-\mathrm{HT}$ to calculate the amount of ${ }^{3} \mathrm{H}-5-\mathrm{HT}$ that was specifically bound to the protein.

Induction of polyclonal antibodies. Anti- $45 \mathrm{kDa}$ and anti-56 kDa SBP sera were raised by immunizing rabbits against the purified proteins (Liu et al., 1985; Adlersberg et al., 1987). Five to six alternating intradermal, subcutaneous, and intramuscular injections (250 $\mu \mathrm{g}$ each) were given at weekly intervals.

Purification of antibodies to SBP. The antisera to the 2 forms of SBP were purified by passing the crude antisera $(2 \mathrm{ml})$ through a DEAEAffi-blue gel column $(1 \times 3.5 \mathrm{~cm})$ equilibrated with a Tris- $\mathrm{HCl}(0.1 \mathrm{M}$, pH 8.0) buffer that contained $28 \mathrm{~mm} \mathrm{NaCl}$. The IgG fraction $(18 \mathrm{mg})$ was then eluted from the columns with the same buffer. The material eluting from the DEAE-Affi-blue column was further purified by affinity chromatography. An immunoaffinity column was prepared by conjugating the purified 45 or $56 \mathrm{kDa}$ form of SBP (1 mg) overnight with cyanogen bromide-activated Sepharose $4 \mathrm{~B}(1.0 \mathrm{ml})$ in coupling buffer $\left(0.1 \mathrm{M} \mathrm{NaHCO}_{3}, \mathrm{pH} 8.3\right)$ containing $0.5 \mathrm{M} \mathrm{NaCl}$ at $4^{\circ} \mathrm{C}$. Excess ligand was washed away with coupling buffer and remaining active groups on the Sepharose were blocked by shaking the suspension with $0.1 \mathrm{M}$ Tris-
$\mathrm{HCl}$ buffer $(\mathrm{pH} 8.0)$ at room temperature for $2 \mathrm{hr}$. The SBP-Sepharose gels were poured into a column $(0.6 \times 4 \mathrm{~cm})$ and equilibrated with $\mathrm{KPO}_{4}$ buffer $(20 \mathrm{~mm}$, pH 7.5$)$. The IgG fraction $(18 \mathrm{mg})$, obtained from the DEAE-Affi-blue columns, was applied to the affinity columns at $4^{\circ} \mathrm{C}$ and allowed to interact overnight. Unbound protein was then washed from the columns with the same buffer and the bound antibody was eluted with $1.0 \mathrm{M}$ acetic acid. The eluted material was immediately neutralized with Tris base.

Absorption of anti-SBP sera. Samples of antisera containing $15 \mathrm{mg}$ of protein were applied to affinity columns to which either the purified 45 or $56 \mathrm{kDa}$ form of SBP was covalently linked. The same columns were used as described above for the purification of the antisera. Following application of the antisera, the columns were left to stand at $4^{\circ} \mathrm{C}$ overnight. The effluent was passed twice more over the same columns. The sera were considered absorbed when no anti-45 and anti-56 kDa SBP activity was found by enzyme-linked immunoabsorbant assay (ELISA).

Detection and characterization of antibodies. ELISA was used to detect the presence of antibodies against the 2 forms of SBP (Liu et al., 1985). Microtiter wells were coated with $5 \mu \mathrm{g}$ of purified 45 or $56 \mathrm{kDa}$ SBP. Nonspecific binding of immunoglobulin was reduced by pretreatment of the wells with $2 \%$ BSA in $0.01 \mathrm{M}$ PBS (pH 7.4) containing $0.05 \%$ Tween-20 (PBS-TW20). For detection of antibodies to SBP, rabbit antiSBP sera, appropriately diluted with PBS-TW20, was then added. Antibodies to one of the 2 forms of SBP were detected by incubation with goat anti-rabbit IgG conjugated to alkaline phosphatase. Alkaline phosphatase activity was visualized using $p$-nitrophenol phosphate as a substrate and an ELISA reader (Dynatech) with a $412 \mathrm{~nm}$ filter.

Immunochemical tests for monospecificity of antibodies were done on nitrocellulose transfers made from slab gels of crude $0-30 \%\left(\mathrm{NH}_{4}\right)_{2} \mathrm{SO}_{4}$ fractions of soluble brain protein (Towbin et al., 1979). In brief, a strip of the nitrocellulose blot was stained with amido black to detect the transferred proteins, while the remaining blots were prepared for immunostaining. The nitrocellulose strips were soaked in $5 \%$ nonfat dry milk solids (Carnation) dissolved in PBS-TW20 for $1 \mathrm{hr}$ at room temperature. Following several washes, the strips were incubated with purified antibodies to SBP (diluted in PBS containing 5\% nonfat dry milk solids). Immunoreactivity was detected with goat anti-rabbit IgG (diluted $1: 10,000$ in PBS-TW20) conjugated to HRP, and the color reaction was devcloped as described by Sternberger (1979), using 3,3'-diaminobenzidine tetrahydrochloride and $\mathrm{H}_{2} \mathrm{O}_{2}$.

Tissue preparation. Young adult male rats (200-260 gm) were used in this study. All animals were pretreated $2.5-3.0 \mathrm{hr}$ before they were killed with intraperitoneal injections of L-tryptophan $(300 \mathrm{mg} / \mathrm{kg})$ and a MAO inhibitor (pargyline; $100 \mathrm{mg} / \mathrm{kg}$ ) in order to increase the concentration of 5-HT in the brain. In some animals, colchicine $(75 \mu \mathrm{g} / 10$ $\mu$ l) was also infused stereotaxically into the lateral cerebral ventricles the day before the animals were used in order to prevent axonal transport of SBP out of cell bodies.

Rats were anesthetized with sodium pentobarbital $(50 \mathrm{mg} / \mathrm{kg}$, i.p.) and perfused through the ascending aorta with $0.9 \%$ (wt/vol) saline (at room temperature), followed by a fixative solution composed of $4 \%$ (wt/ vol) formaldehyde (from paraformaldehyde) in $0.1 \mathrm{~m}$ sodium phosphate buffer $\left(\mathrm{pH} 7.2,4^{\circ} \mathrm{C}\right.$ ) containing $0.1 \%(\mathrm{wt} / \mathrm{vol}) \mathrm{MgSO}_{4}$ and $6 \%$ (wt/vol) sucrose. The brain and spinal cord were removed, postfixed in fresh fixative solution $\left(4^{\circ} \mathrm{C}\right)$ overnight, and then transferred to $0.1 \mathrm{M}$ phosphate buffer for cutting or storage. Serial coronal sections of the brain and longitudinal sections of the spinal cord were cut at $30-50 \mu \mathrm{m}$ with a Vibratome (Oxford Instruments) and extensively rinsed in buffer (2-3 hr) to remove fixative.

Immunostaining of a single antigen. Nonfat dry milk solids (Carnc tion; $5 \%$ ) were used to block nonspecific staining because horse serul was found to have immunoreactivity (Barasch et al., 1987b). The milk solids were present in all solutions except those containing avidinalkaline phosphatase. Sections of brain and spinal cord were incubated with milk solids for $30 \mathrm{~min}$ and then for $24-48 \mathrm{hr}$ at $4^{\circ} \mathrm{C}$ with partially purified antisera to the $45 \mathrm{kDa}$ (diluted 1:200) or affinity-purified antisera to the $56 \mathrm{kDa}$ (1:50) forms of SBP. Sections were then washed with $0.1 \mathrm{~m}$ phosphate buffer and incubated for $1 \mathrm{hr}$ at room temperature with biotinylated goat anti-rabbit serum (diluted 1:400; Kirkegaard and Perry) and subsequently for $1 \mathrm{hr}$ with alkaline phosphatase-labeled avidin (diluted 1:400; Vector Laboratories). All sera contained $0.5-1.0 \%$ Triton $\mathrm{X}-100$ to enhance penetration of the immunoreagents. The alkaline phosphatase-labeled antigens were made visible by using an alkaline phosphatase substrate kit (Vector Laboratories; Kit III) that produced 
a blue reaction product. The staining was performed in the presence of $1 \mathrm{~mm}$ levamisole (Sigma) to inhibit endogenous alkaline phosphatase (Ponder and Wilkinson, 1981). In addition, the substrate solution contained $10 \mathrm{mM} \mathrm{MgCl}_{2}$, which potentiates alkaline phosphatase activity (DeJong et al., 1985). Sections were reacted in the dark with the substrate solution for 30-60 min or until the blue immunoreaction product was seen. Sections were then washed in distilled water, dehydrated with ethanol, cleared in Histoclear (National Diagnostics), and coverslipped with Permount.

To compare the distributions of 45 and $56 \mathrm{kDa}$ SBP immunoreactivities with that of 5-HT, adjacent sections were incubated with a rat monoclonal antibody to 5-HT (diluted 1:200; Sera Laboratories). 5-HT immunoreactivity was localized by using a biotinylated anti-rat secondary antibody (diluted 1:400; Kirkegaard and Perry), followed by avidin-alkaline phosphatase (1:400), visualized as described above.

Simultaneous immunostaining of 2 antigens. Two procedures were used to evaluate the possible coexistence of SBP and 5-HT in the same neurons in the brain and spinal cord. One employed double-immunofluorescence with tetramethylrhodamine isothiocyanate (TRITC)- and fluoroscein isothiocyanate (FITC)-labeled secondary antibodies or avidin. The other used the peroxidase anti-peroxidase (PAP) technique (Sternberger, 1979) to show one antigen- and alkaline phosphataselabeled avidin to demonstrate the other. In both procedures, the 2 antigens were sequentially immunostained in the same tissue sections, using primary antisera raised in different species in combination with species-specific secondary antisera. For double-immunofluorescence, nonfat dry milk solids were used to block nonspecific staining, sections were incubated with a rat monoclonal antiserum to 5-HT and TRITClabeled goat anti-rat sera (diluted 1:200 for $3 \mathrm{hr}$ at room temperature; Kirkegaard and Perry). Tissues were then washed extensively and incubated for $24-48 \mathrm{hr}$ at $4^{\circ} \mathrm{C}$ with either the antiserum to $45 \mathrm{kDa}$ SBP or with that to $56 \mathrm{kDa}$ SBP. A biotinylated goat anti-rabbit secondary antiserum (diluted 1:400; Kirkegaard and Perry) was then applied for $1 \mathrm{hr}$ at room temperature. Sites of SBP immunoreactivity were exposed using FITC-labeled avidin (diluted 1:200; Vector). Immunoreactive structures were visualized using a Leitz fluorescence microscope equipped for vertical illumination. An $\mathrm{N}_{2}$ filtcr/dichroic mirror cube was used to detect TRITC fluorescence, and an $L_{2}$ cube was used for FITC. There was no cross detection between the TRITC- and FITC-selective filter/ dichroic mirror cubes.

For dual immunoenzymatic detection, 5-HT immunoreactivity was demonstrated first using the PAP technique. Sections, incubated as above with rat monoclonal antibody to 5-HT, were washed and treated for 1 $\mathrm{hr}$ at room temperature with goat anti-rat IgG (diluted 1:40; Kirkegaard and Perry). Following a further wash, the sections were exposed to rat monoclonal PAP (diluted 1:100; Sternberger and Mayer) for $1 \mathrm{hr}$ at room temperature. After washing with $0.1 \mathrm{M}$ phosphate buffer, 5-HT

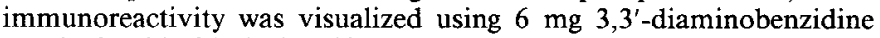
tetrahydrochloride (DAB; Sigma) and glucose/glucose oxidase (Sigma) to generate $\mathrm{H}_{2} \mathrm{O}_{2}$. The progress of the reaction was monitored with a dissecting microscope and stopped as soon as the brown reaction product became visible. The DAB polymer deposited at sites of immunoreactivity masks the antigen and catalytic sites of the first sequence of immunoreagents and prevents interaction with reagents of the second sequence (Sternberger and Joseph, 1979). For this reason, the PAP/ DAB procedure was done first. PAP-labeled sections were then incubated with antisera to 45 or $56 \mathrm{kDa}$ SBP and sites of SBP immunoreactivity were visualized using the alkaline phosphatase method described above. Following this procedure, 5-HT immunoreactivity was localized by a brown, and SBP immunoreactivity by a blue reaction product. Doubly labeled cells could be recognized by their combined color.

Controls. Control procedures included the substitution of preimmune sera for the primary antisera, incubation with absorbed sera, and reversing the 5-HT and SBP primary antisera, while processing the tissuc sections exactly as described above. Immunostaining was considered specific only if no reaction product was demonstrable following incubation of sections with preimmune or absorbed sera. In double-labeling experiments, immunostaining was considered specific only if no reactivity could be demonstrated when tissues were treated with rat antibodies to 5-HT followed by anti-rabbit sera or with rabbit anti-SBP sera followed by a secondary anti-rat serum. These experiments, in which secondary antisera were switched, were designed to eliminate the possibility of cross-reactivity of immune reagents. This possibility was further reduced by comparing the results obtained by simultaneous immunolocalization of 5-HT and SBP with the demonstration of each of these antigens alone, and by employing 2 different methods of dual immunodetection. Finally, additional experiments were done with primary antibodies to antigens-substance $P$ (rat monoclonal) and vasoactive intestinal polypeptide (rabbit polyclonal) - known not to be colocalized in the submucosal plexus (Costa et al., 1987). These antigens were localized with the same secondary antisera used in the present study. No apparent coexistence was seen, indicating that the secondary antiscra do not cross-rcact.

\section{Results}

Preparation and characterization of antisera to 45 and $56 \mathrm{kDa}$ SBP

Purified $45 \mathrm{kDa}$ and $56 \mathrm{kDa}$ SBP (Liu et al., 1985; Adlersberg et al., 1987) were used to raise antibodies in rabbits. The proteins were found to be more antigenic when injected withoul an adjuvant. After 6 injections, given at weekly intervals, immunoreactivity was detected in the serum of the injected animals by ELISA assay. Absorption of the sera with purified 45 and 56 $\mathrm{kDa}$ SBP immobilized on columns removed the immunoreactivity. The crude sera were then partially purified by ammonium sulfate fractionation and chromatography on DEAE-Affi-blue gel columns. The IgG fractions thus obtained were tested for monospecificity by subjecting ammonium sulfate-precipitated brain proteins to PAGE and immunoblot analysis with the antiSBP sera (Fig. 1). Although amido black staining of nitrocellulose blots demonstrated the transfer of virtually all of the proteins that had been present in the original polyacrylamide gel following PAGE (Fig. 1, lane $A$ ), only one major band of protein, corresponding in electrophoretic mobility to $45 \mathrm{kDa}$, reacted with the partially purified anti- $45 \mathrm{kDa}$ SBP sera (Fig. 1, lane $B$ ). On the other hand, several bands reacted with anti-56 $\mathrm{kDa}$ sera. Nevertheless, the major band of protein that was immunoreactive with anti-45 kDa SBP sera was not labeled by the antiserum to $56 \mathrm{kDa}$ SBP. The antisera to $45 \mathrm{kDa}$ and 56 kDa SBP, therefore, do not cross-react. These sera also failed to cross-react in ELISA assays (data not shown). Absorbed 45 kDa SBP antisera (Fig. 1, lane $C$ ) and preimmune sera did not immunolabel proteins on the immunoblots.

Since more than one protein reacted with anti- $56 \mathrm{kDa}$ sera, further purification of this serum was necessary. This was accomplished by affinity chromatography. The partially purified $\mathrm{IgG}$ fraction was applied to a column to which $56 \mathrm{kDa}$ SBP was covalently bound. Nonimmunoreactive IgG was washed from the column and the specifically bound antibodies were subsequently eluted at low pH (Fig. $2 A$ ). ELISA assay showed that the antibodies had been purified about 20 -fold by this procedure and that the immunorcactivity was lincar with respect to protcin concentration (Fig. $2 B$ ). Analysis of affinity-purified anti-56 kDa sera on immunoblots revealed immunoreactivity only of a single major band, corresponding in electrophoretic mobility to 56 $\mathrm{kDa}$ (Fig. 3, lane $B$ ). No immunoreactivity was detected in absorbed anti-56 kDa SBP sera (Fig. 3, lane $C$ ).

Due to the similarity in $M_{\mathrm{r}}$ between $45 \mathrm{kDa}$ SBP and actin, we tested the possibility that antiserum to $45 \mathrm{kDa}$ SBP recognized G-actin (generously supplied by Dr. Sol Berl, Mount Sinai Medical School). The antiserum to $45 \mathrm{kDa}$ SBP failed to react with immobilized G-actin in ELISA assays. Moreover, 3 different monospecific antibodies to G-actin (generously supplied by Dr. Beverly Lubit, Rutgers University Medical School, Dr. Daniel Goldberg, Columbia University, and obtained commercially from Miles-Yeda) also failed in ELISA assays to react with $45 \mathrm{kDa}$ SBP. Finally, actin bound to Sepharose columns 


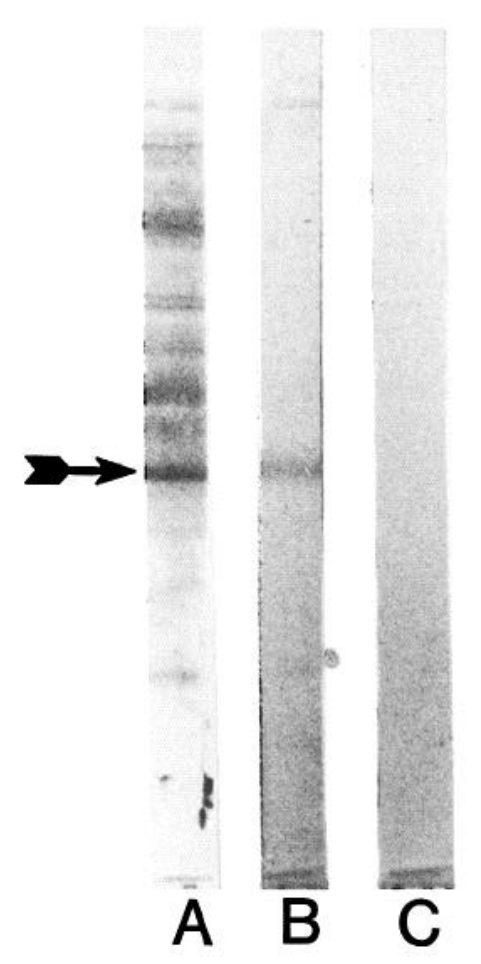

Figure 1. Immunoblot analysis of partially purified anti-45 kDa SBP serum. Lane $A$, Amido black stain showing proteins (from the 100,000 $\times g$ supernatant of rat brain homogenate precipitated by $\left(\mathrm{NH}_{4}\right)_{2} \mathrm{SO}_{4}$ at $0-30 \%$ saturation) transferred from a polyacrylamide slab gel to a nitrocellulose sheet. Lane $B$, Immunostain of the nitrocellulose sheet using the anti- $45 \mathrm{kDa}$ serum as the primary antibody. Immunoreactivity was detected using an HRP-labeled secondary antiserum. Peroxidase activity was visualized using DAB. There is a single immunoreactive band. Lane $C$, Immunostain of the nitrocellulose sheet done exactly as in lane $B$, except that the anti-45 $\mathrm{kDa}$ serum was absorbed with purified 45 $\mathrm{kDa}$ SBP. Note that there is no longer any detectable immunoreactivity.

to which DNase was covalently linked (Lazarides and Lindberg, 1974), while $45 \mathrm{kDa}$ SBP passed through these columns in the void volume.

\section{Localization of $45 \mathrm{kDa}$ and $56 \mathrm{kDa}$ SBP immunoreactivity}

SBP immunoreactivity was found in rat brain and spinal cord (see below for localization). Numerous punctate deposits of blue alkaline phosphatase reaction product were seen in a discrete distribution in both the brain and spinal cord following application of either anti-45 kDa or anti-56 kDa SBP serum. Sites of SBP immunoreactivity $\left(\mathrm{SBP}^{+}\right)$often surrounded nonreacted neuronal cell bodies. No significant differences were observed in the pattern of distribution of $45 \mathrm{kDa}^{+}$and $56 \mathrm{kDa} \mathrm{SBP}{ }^{+}$ structures. Because of their pattern, the punctate deposits were thought to probably represent the terminal varicosities of immunostained axons. No neuronal perikarya were immunostained by either SBP antiserum in the absence of colchicine. When animals were pretreated with colchicine, $\mathrm{SBP}^{+}$neuronal perikarya were found. The localization of 5-HT-immunoreactive $\left(5-\mathrm{HT}^{+}\right)$neuronal perikarya was not dependent on colchicine pretreatment, and colchicine did not alter the distribution of $5-\mathrm{HT}^{+}$cells. The distribution of $5-\mathrm{HT}^{+}$neurons found in the present study was similar to that previously reported for serotonergic neurons (Dahlström and Fuxe, 1964; Steinbusch, 1981). Neurons labeled by anti- 45 and anti-56 kDa SBP sera were found primarily in the nuclei of the median raphe in the brain
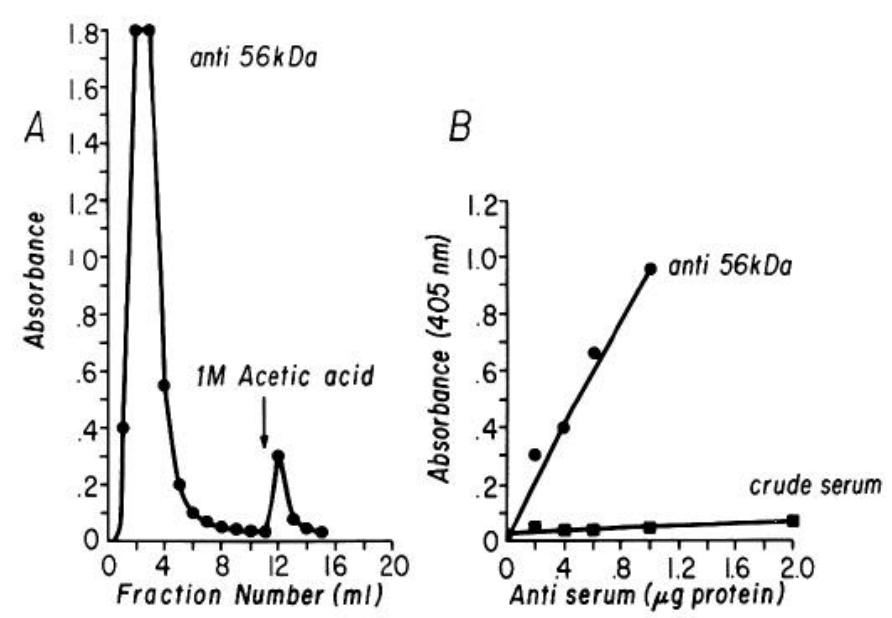

Figure 2. Purification and characterization of antiserum to $56 \mathrm{kDa}$ SBP. $A$, Crude anti-56 kDa serum was fractionated on an affinity column to which purified $56 \mathrm{kDa}$ SBP was coupled. The elution profile is shown. The bulk of the protein passed through the column in the void volume. Specific antibodies to $56 \mathrm{kDa}$ SBP were eluted with $1.0 \mathrm{~N}$ acetic acid (arrow). B, ELISA assay (absorbance of alkaline phosphatase reaction product) of the anti-56 kDa SBP immunoreactivity in the antisera before (crude serum) and after (anti-56 kDa) passage the affinity column. Note the concentration of immunoreactivity that has taken place in the specific anti-56 kDa SBP serum.

stem (Figs. $4 A, 5 A$ ). No difference was noted in the pattern of the 45 and $56 \mathrm{kDa} \mathrm{SBP}{ }^{+}$neurons. The distribution of neurons labeled by each antiserum to SBP was similar to that of 5-HT+ neurons studied in adjacent serial sections (Figs. $4 B, 5 B$ ).

$\mathrm{SBP}^{+}$neuronal perikarya were present in the nuclei raphe dorsalis (Fig. $4 A$ ), raphe centralis superior, raphe medianus, raphe magnus, raphe obscurus (Fig. $5 A$ ), and raphe pallidus. 5 - $\mathrm{HT}^{+}$neuronal perikarya (Figs. $4 B, 5 B$ ) were observed in the same regions and had a morphology similar to that of the neurons labeled by antisera to SBP. For example, in the median zone of the nucleus raphe dorsalis, $\mathrm{SBP}^{+}$(Fig. $4 A$ ) and $5-\mathrm{HT}^{+}$ (Fig. $4 B$ ) neurons were characteristically small and mostly round in shape, with few processes; however, between the 2 medial longitudinal fasciculi, they tended to be fusiform, with vertically oriented dendrites. In the nucleus raphe obscurus, $\mathrm{SBP}^{+}$(Fig. $5 A$ ) and $5-\mathrm{HT}^{+}$(Fig. $5 B$ ) neurons were large, multipolar, and located in 2 parallel vertical laminae adjacent to the midline.

$\mathrm{SBP}^{+}$perikarya were observed in nuclei where serotonergic neurons have previously been reported outside the median raphe. For example, serotonergic neurons have been detected histochemically (Fuxe and Ungerstedt, 1968) and immunocytochemically (Steinbusch et al., 1982) dorsal to the medial lemniscus in the region of the B9 cell group of Dahlström and Fuxe (1964) and in the interpeduncular nucleus. In the current study, the B9 cell group was found to be $\mathrm{SBP}^{+}$(Fig. $6 A$ ), and a small number of $\mathrm{SBP}^{+}$cells were seen in the paramedian section of the interpeduncular nucleus (Fig. $7 A$ ). $5-\mathrm{HT}^{+}$neurons were also found in the vicinity of the medial lemniscus and in the paramedian section of the interpeduncular nucleus (Figs. $6 B, 7 B$ ). Additional extra-raphe regions where serotonergic neurons have been reported following pretreatment of animals with an MAO inhibitor and 5-HT or a precursor of 5-HT include the area postrema, the pars compacta of the substantia nigra, the dorsomedial nucleus of the hypothalamus, and the arcuate nucleus (Fuxe and Ungerstedt, 1968; Kent and Sladek, 1978; Beaudet and Des- 


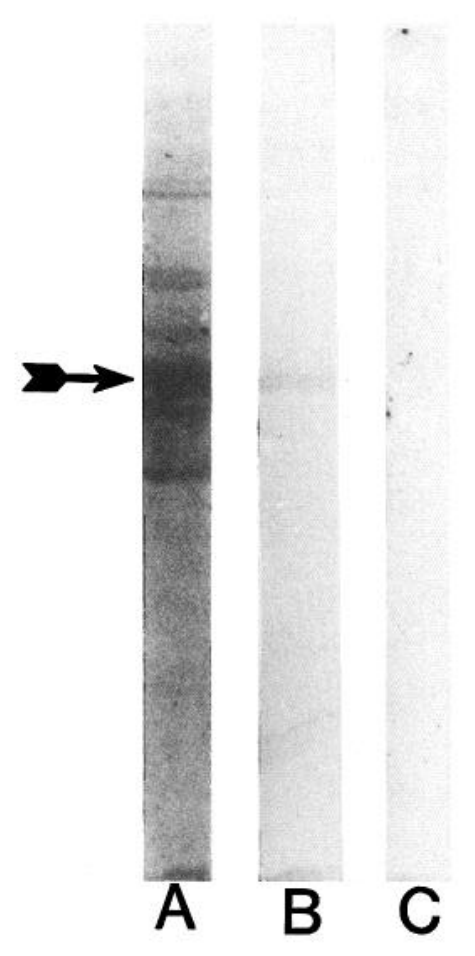

Figure 3. Immunoblot analysis of anti- $56 \mathrm{kDa}$ SBP antibodies affinitypurified as in Figure 2. Lane $A$, Amido black stain showing proteins (from the $100,000 \times g$ supernatant of rat brain homogenate precipitated by $\left(\mathrm{NH}_{4}\right)_{2} \mathrm{SO}_{4}$ at $0-30 \%$ saturation) transferred from a polyacrylamide slab gel to a nitrocellulose sheet, Lane $B$, Immunostain of the nitrocellulose sheet using the acetic acid eluate from the $56 \mathrm{kDa}$ SBP affinity column (see Fig. 2) as the primary antibody. Immunoreactivity was detected using an HRP-labeled secondary antiserum. Peroxidase activity was visualized with DAB. There is a single immunoreactive band. Lane $C$, Immunostain of the nitrocellulose sheet done exactly as in lane $B$, except that the anti- $56 \mathrm{kDa}$ antibodies were absorbed with purified $56 \mathrm{kDa}$ SBP. Note that there is no longer any detectable immunoreactivity.

carries, 1979; Frankfurt et al., 1981; Steinbusch et al., 1982). $\mathrm{SBP}^{+}$and $5-\mathrm{HT}^{+}$perikarya were encountered in these regions.

Although $\mathrm{SBP}^{+}$neuronal cell bodies were confined primarily to the rhombencephalon and the tegmentum of the midbrain, $\mathrm{SBP}^{+}$fibers and terminals were present in many additional areas of the brain, as well as in the spinal cord; moreover, the distribution of these $\mathrm{SBP}^{+}$fibers paralleled that of those immunostained with antibodies to 5-HT. Areas in which the neuropil, but not neuronal cell bodies, were immunostained both by antiSBP sera and antibodies to 5-HT included the cerebellum and hippocampus. In the hippocampus, a dense $\mathrm{SBP}^{+} / 5-\mathrm{HT}^{+}$band was found in the stratum lacunosum moleculare of areas CA1 and CA2, and in the infragranular layer of the dentate gyrus. Somewhat fewer SBP and 5-HT immunoreactivities were detected in the hilus fasciae dentatae. An $\mathrm{SBP}^{+} / 5-\mathrm{HT}^{+}$band was also observed in the alveus, which suggests that $\mathrm{SBP}^{+}$and $5-\mathrm{HT}^{+}$ axons enter the hippocampus in this structure. Additional CNS regions that were found in the current study to display SBP and 5-HT immunoreactivity included the lateral geniculate nucleus (Fig. $8, A, B$ ), periventricular gray matter (under the fourth ventricle; not illustrated), and the midbrain raphe nuclei (Figs. $4 A, 5 A$ ). The globus pallidus and regions of the hypothalamus contained smaller numbers of $\mathrm{SBP}^{+}$and $5-\mathrm{HT}^{+}$fibers (Fig. 8, $C, D)$. A moderately dense network of $\mathrm{SBP}^{+}$fibers was found in the rat spinal cord (Fig. $9 A$ ), where the SBP+ fibers were found in the ventral funiculus in a pattern that was similar to that of 5-HT+ ${ }^{+}$axons (Fig. 9B). The supraependymal plexus lining the ventricular surfaces also contained a dense network of $\mathrm{SBP}^{+}$and

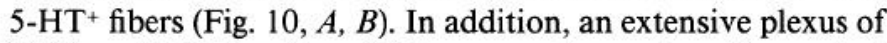
$\mathrm{SBP}^{+}$and $5-\mathrm{HT}^{+}$cells and fibers was observed on the ventral surface of the caudal hypothalamus and medulla (Fig. 10, C, D).

\section{Coexistence of SBP and 5-HT immunoreactivities}

The similar distributions of 45 and $56 \mathrm{kDa} \mathrm{SBP}{ }^{+}$and $5-\mathrm{HT}^{+}$ fibers is consistent with, but not proof of, the hypothesis that 5 -HT is colocalized with the 2 forms of SBP. In order to test this hypothesis, an attempt was made to locate $45 \mathrm{kDa}$ and 56 kDa SBP immunoreactivities simultaneously with 5-HT in the same tissue sections. This was accomplished by using speciesspecific secondary antisera, since the primary antisera to the 2 forms of SBP were raised in rabbits, while a rat monoclonal antibody was used for 5-HT. 5-HT and SBP immunoreactivities were found to be colocalized in both the brain and spinal cord. Most cells and fibers found to be stained by one immunoreagent were also stained by the other (occasional cells showed SBP, but not 5-HT, immunoreactivity). Colocalization was detected no matter whether double-immunofluorescence or double immunoenzymatic staining procedures were used for detection of the antigens. Examples of the coexistence of $5-\mathrm{HT}^{+}$and 45 or 56 $\mathrm{kDa} \mathrm{SBP}^{+}$neurons and processes in and outside the raphe nuclei are shown in the nucleus raphe dorsalis (Fig. 11) region of the B9 cell group of Dahlström and Fuxe (Fig. 12), the area postrema, pars compacta of the substantia nigra, dorsomedial hypothalamic nucleus, and arcuate nucleus. SBP immunoreactivity also colocalized with 5-HT immunoreactivity in fibers in the spinal cord (Fig. 13).

\section{Controls}

No immunostaining was seen when sections were treated with anti-45 kDa SBP sera absorbed with $45 \mathrm{kDa}$ SBP, anti-56 kDa SBP sera absorbed with $56 \mathrm{kDa}$ SBP, or anti-5-HT sera absorbed with 5-HT conjugated to BSA. Moreover, no immunostaining was observed when preimmune sera were substituted for the primary antisera or when primary antisera were switched. Sections incubated only with secondary and tertiary antibodies were also unstained.

\section{Discussion}

The $56 \mathrm{kDa}$ and $45 \mathrm{kDa}$ forms of SBP have previously been identified and purified (Liu et al., 1985; Adlersberg et al., 1987). We have now prepared polyclonal antisera to these proteins. The antiserum to the $56 \mathrm{kDa}$ SBP required affinity purification, but both the anti- 45 and the affinity-purified anti-56 kDa SBP sera were found to be monospecific. The immunoreactivity of both sera thus was completely removed by passage through columns to which the corresponding form of SBP was covalently bound. Moreover, both the anti-45 kDa and the affinity-purified anti-56 kDa SBP sera reacted in immunoblots only with a single band at the appropriate $M_{\mathrm{r}}$. The antiserum to $56 \mathrm{kDa}$ SBP failed to react with $45 \mathrm{kDa} \mathrm{SBP}$ and the antiserum to $45 \mathrm{kDa} \mathrm{SBP}$ failed to react with $56 \mathrm{kDa}$ SBP; therefore, the 2 antisera recognized different epitopes and were type-specific. Such a difference in immunospecificity could occur if there were 2 different 5-HT-binding proteins; however, previously generated antibodies to the 2 types of SBP have recognized both 45 and $56 \mathrm{kDa}$ 


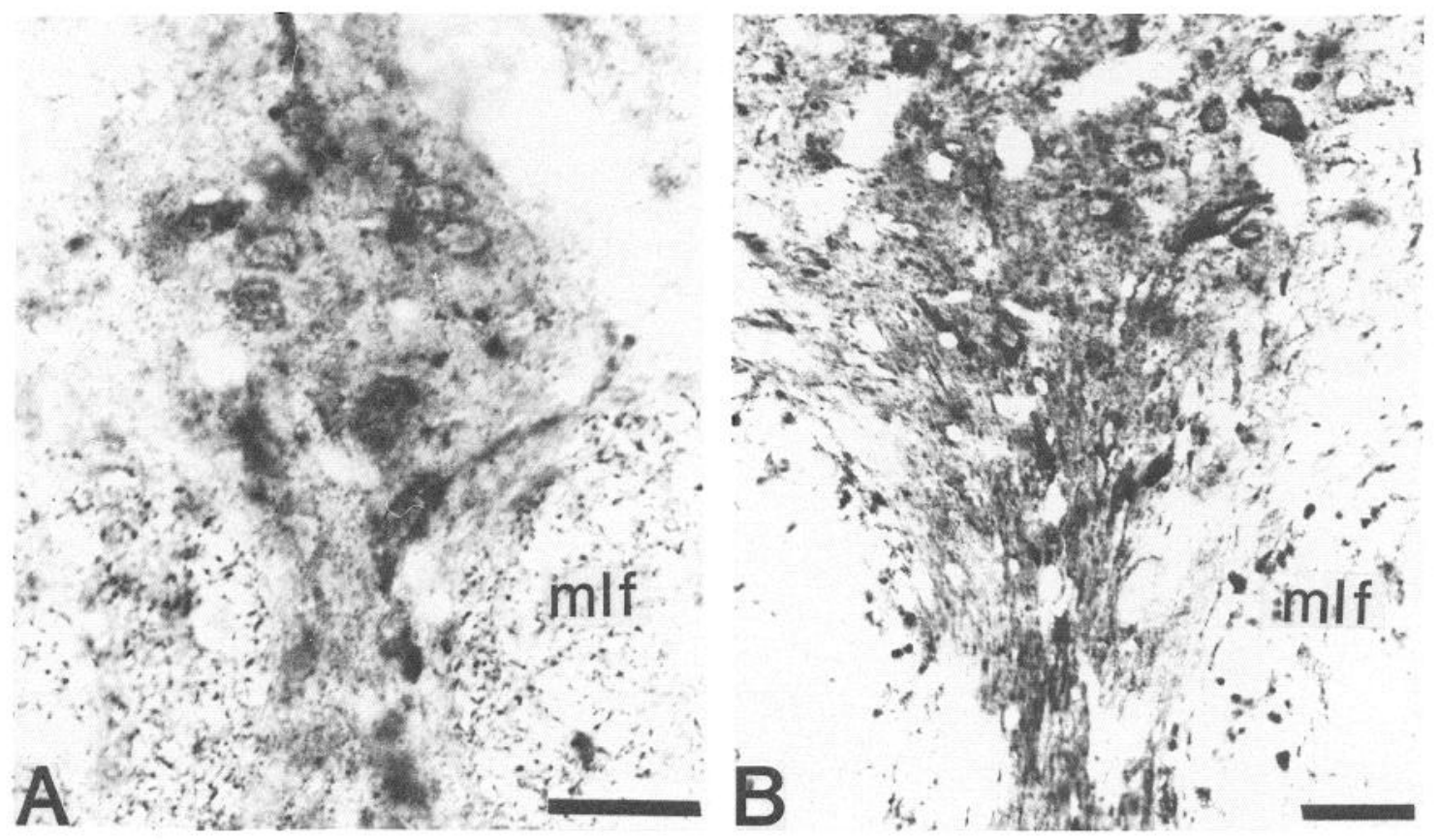

Figure 4. Rostral nucleus raphe dorsalis. (Single-label immunodetection.) A, Vibratome section exposed to partially purified antibodies to $45 \mathrm{kDa}$ SBP (see Fig. 1). Immunoreactivity is seen in numerous small round cell bodies and in the surrounding neuropil. $B$, Serial section exposed to antibodies to 5-HT. The pattern of immunoreactivity is similar to that seen with antibodies to $45 \mathrm{kDa}$ SBP. mlf, medial longitudinal fasciculus. Bars, $50 \mu \mathrm{m}$.

SBP (Liu et al., 1985). It thus seems more likely that there is a larger and a smaller form of SBP, separate domains of which are recognized by the 2 antisera. Prior studies have suggested that the $56 \mathrm{kDa}$ SBP is preferentially located in cell bodies of serotonergic neurons and is the precursor of the $45 \mathrm{kDa}$ form of the molecule, which is preferentially located in axon terminals (Gershon et al., 1983). This suggestion, as well as the idea that SBP is an intrinsic component of serotonergic neurons, was tested immunocytochemically. Also evaluated was the suggestion of Small and Wurtman (1984) that SBP is a form of actin.
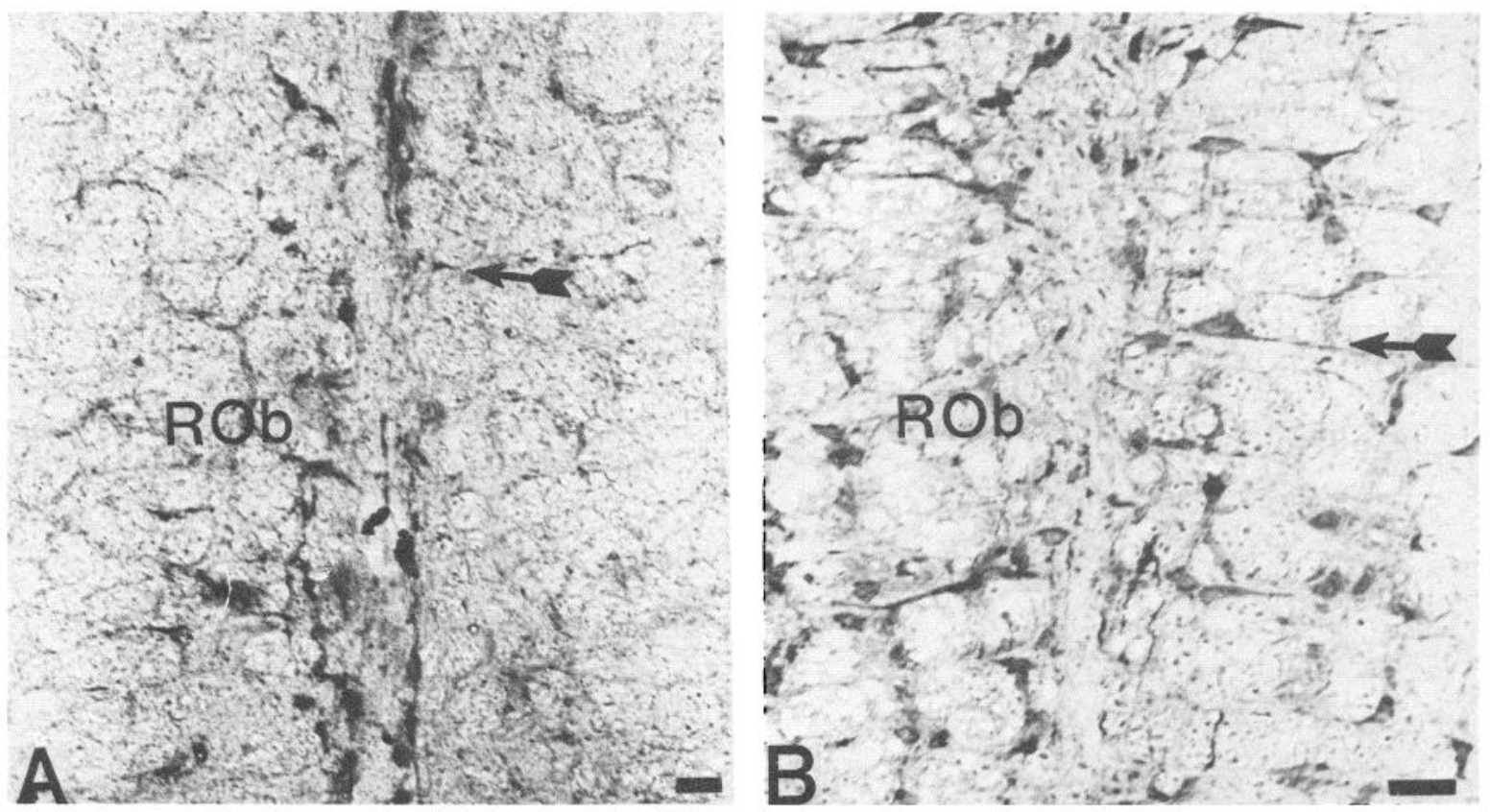

Figure 5. Nucleus raphe obscurus $(R O b)$. (Single-label immunodetection.) $A$, Vibratome section exposed to partially purified antibodies to 45 $\mathrm{kDa}$ SBP. Immunoreactivity is seen in large, multipolar nerve cell bodies that form 2 distinct parallel rows running vertically adjacent to the midline. Note the immunoreactive dendrites and dendritic bundles extending horizontally (arrows) into the midline region and the proximate reticular formation, $B$, Serial section exposed to antibodies to $5-\mathrm{HT}$. The pattern of immunoreactivity is similar to that seen with antibodies to 45 $\mathrm{kDa}$ SBP. Bars, $50 \mu \mathrm{m}$. 

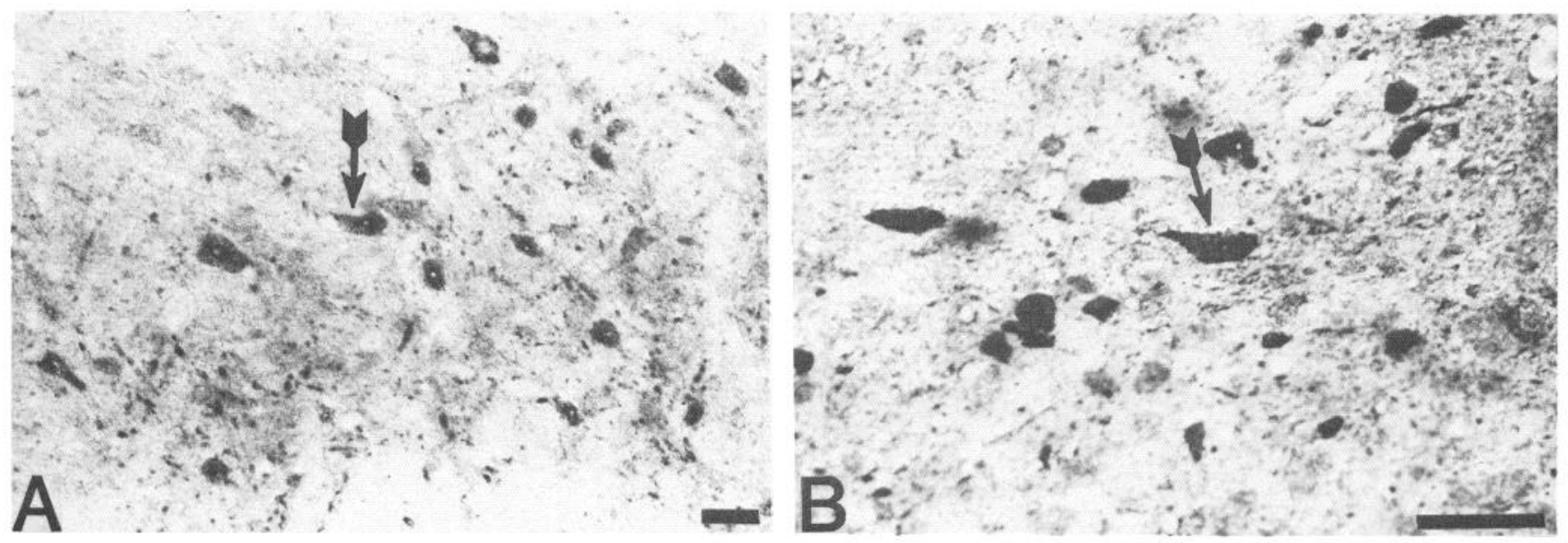

Figure 6. Group B9 of Dahlström and Fuxe (1964). (Single-label immunodetection.) A, Vibratome section exposed to affinity-purified antibodies to $56 \mathrm{kDa}$ SBP. Numerous medium-sized nerve cell bodies dorsal to the medial lemniscus are immunoreactive. There is also an abundance of punctate immunostaining in the surrounding neuropil. $B$, Serial section exposed to antibodies to 5-HT. The pattern of immunoreactivity is similar to that seen with antibodies to $56 \mathrm{kDa}$ SBP. Note that some neurons with the same distinct shape are stained with either immune reagent (arrows). Bars, $50 \mu \mathrm{m}$.

Immunocytochemical results showed that both $45 \mathrm{kDa}$ and $56 \mathrm{kDa}$ forms of SBP colocalized with 5-HT immunoreactivity in the cell bodies of neurons both within and outside the nuclei of the median raphe. Wherever 5-HT immunoreactivity could be demonstrated, both forms of SBP were also found. Moreover, no differences could be detected, despite the use of type-specific anti-SBP sera, in the localization of either the 45 or the $56 \mathrm{kDa}$ form of SBP. Only rarely could SBP immunoreactivity of either type be found in cells in the brain where 5-HT immunoreactivity could not be detected and no SBP immunoreactivity was seen in glia; therefore, it can be concluded that serotonergic neurons of the CNS contain SBP. Moreover, it also seems likely that serotonergic neurons contain both the $45 \mathrm{kDa}$ and the $56 \mathrm{kDa}$ forms of the molecule, and that non-serotonergic neurons do not have SBP. Anti-SBP sera may be slightly more sensitive reagents than are moncolonal antibodies to $5-\mathrm{HT}$ in the detection of serotonergic neurons. These data thus strongly support the hypothesis that SBP is an intrinsic and a specific component of serotonergic neurons.

Both anti- $45 \mathrm{kDa}$ and anti- $56 \mathrm{kDa}$ sera labeled what appeared to be axons and terminals in those brain areas in which 5-HT immunoreactivity could also be demonstrated in axons and terminals. This observation suggests that both forms of SBP are transported proximodistally in the axons of serotonergic neurons. The idea that SBP is subject to fast axonal transport has previously been proposed on the basis of studies of its rate of accumulation rostral to a spinal cord transection (Gershon et al., 1983). Since, in the present study, the immunoreactivity of both forms of SBP could be detected in processes, but not cell bodies, unless colchicine was administered, it is probable that relatively little SBP normally remains in the perikarya of serotonergic neurons and that most of the protein is translocated to terminals. The action of colchicine in fostering the buildup of SBP in cell bodies is similar to its action in facilitating the

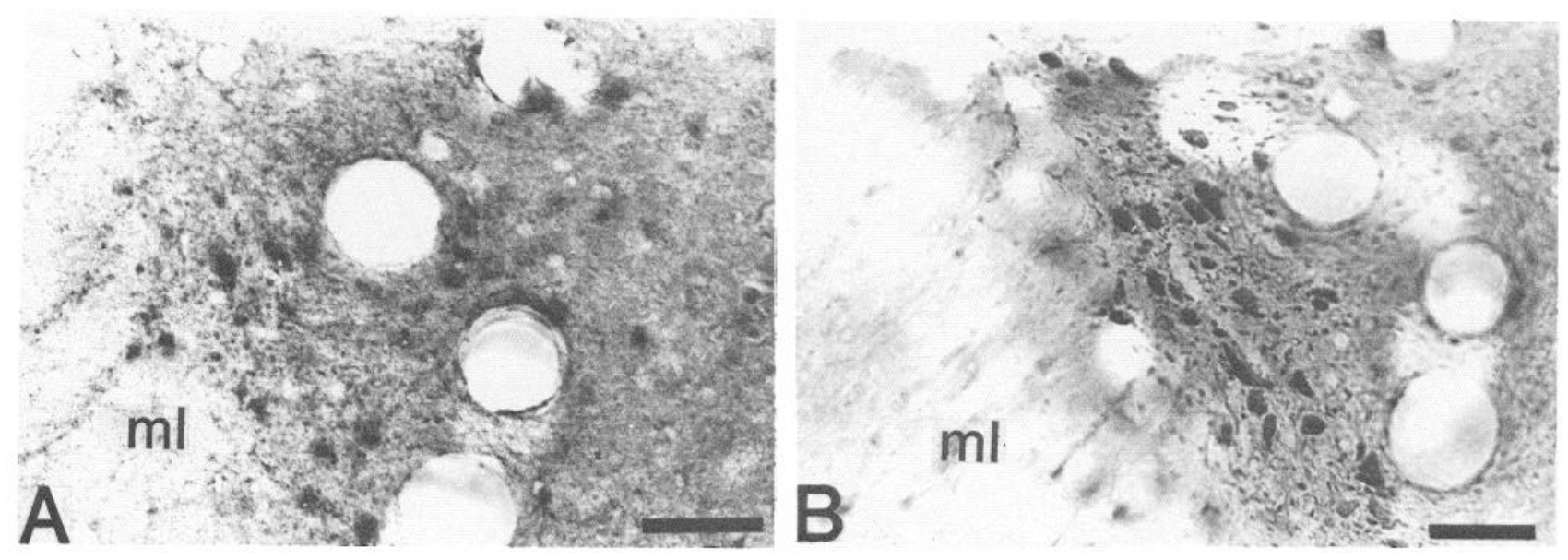

Figure 7. Interpeduncular nucleus. (Single-label immunodetection.) A, Vibratome section exposed to affinity-purified antibodies to $56 \mathrm{kDa}$ SBP. A relatively small number of nerve cell bodies (arrows) are immunostained in the ventral tegmentum in the winglike paramedian division of the interpeduncular nucleus near the medial lemniscus $(m l)$. B. Serial section exposed to antibodies to 5 -HT. The pattern of immunoreactivity is similar to that seen with antibodies to $56 \mathrm{kDa}$ SBP. Bars, $50 \mu \mathrm{m}$. 

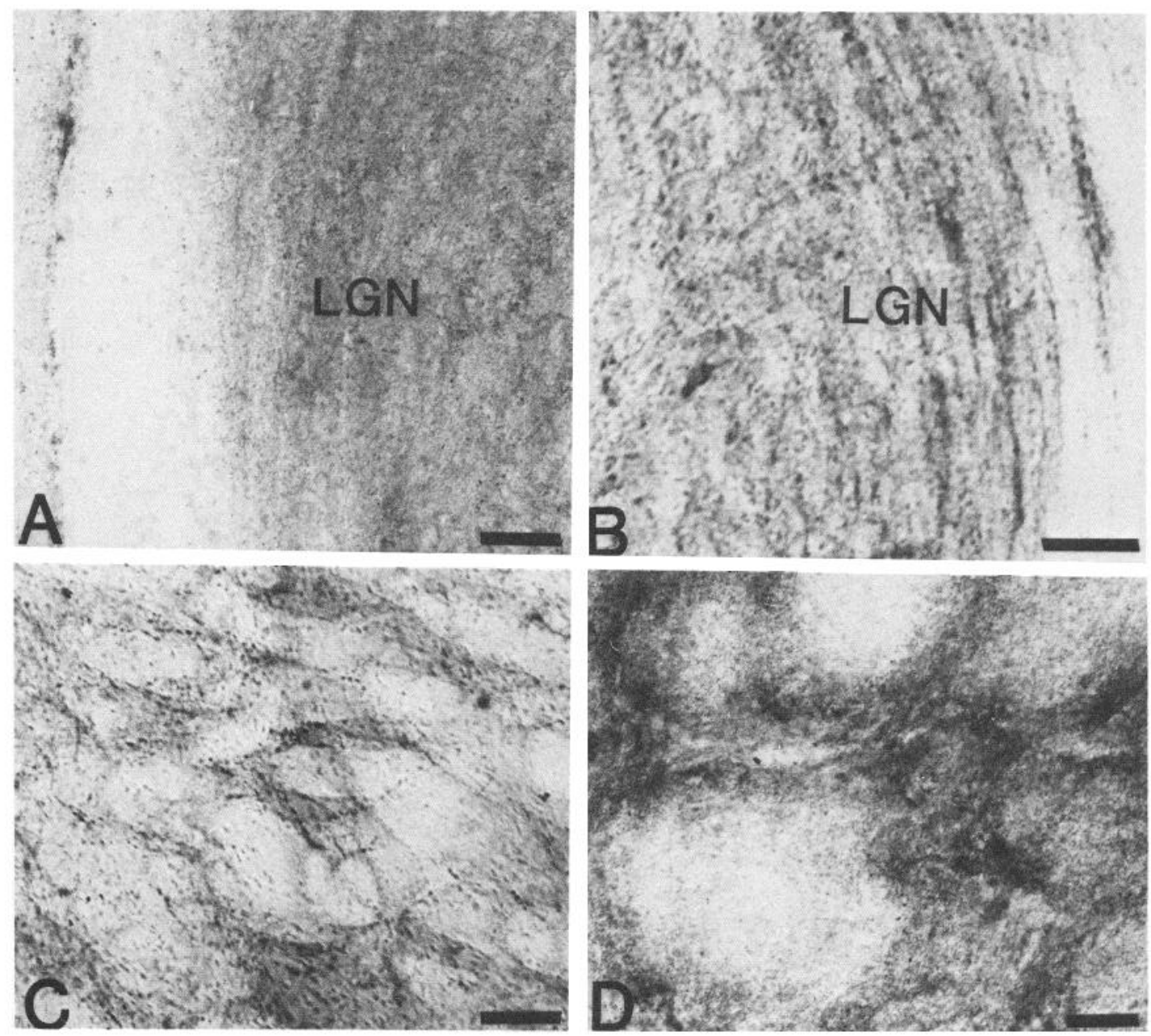

Figure 8. Single-label immunodetection. $A, B$, Lateral geniculate nucleus $(L G N)$. The neuropil is immunoreactive following incubation either with antibodies to $45 \mathrm{kDa}$ SBP $[A]$ or with antibodies to 5 -HT $[B]$. The orientation of the immunoreactive fibers describes alternating arcs of lighter and denser immunostaining. $C, D$, Globus pallidus. The neuropil is immunoreactive following incubation either with antibodies to $45 \mathrm{kDa} S \mathrm{SP}$ $[C]$ or with antibodies to 5-HT $[D]$. Immunoreactive zones surround circular nonreactive fiber tracts. In addition, punctate deposits of immunoreactivity can also be seen. Bars, $50 \mu \mathrm{m}$.

immunocytochemical demonstration of neuropeptides and is consistent with earlier conclusions that SBP is intravesicular (Jonakait et al., 1979; Tamir and Gershon, 1979; Barasch et al., 1987b) and moved to terminals by fast axonal transport (Gershon et al., 1983).
The highly restricted distribution of 45 and $56 \mathrm{kDa}$ SBP immunoreactivities in the brain and spinal cord is not consistent with the idea that SBP is a form of actin. If SBP were a form of actin, then the actin would have to be a subset that is restricted to serotonergic neurons. No previous study has yet found an
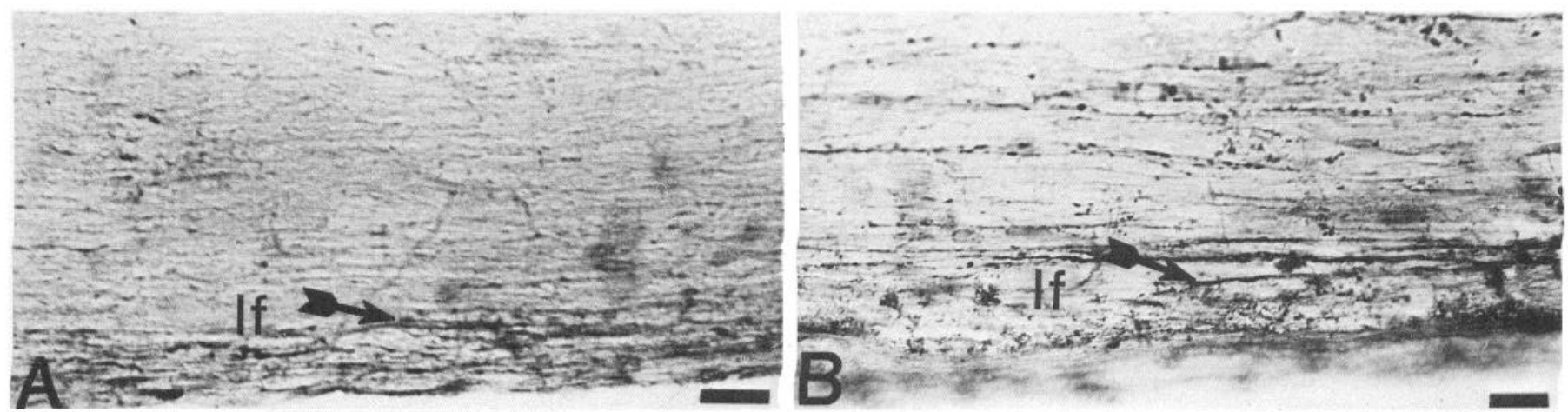

Figure 9. Spinal cord. (Single-label immunodetection.) A, Vibratome section cut horizontally through the cervical cord and exposed to affinitypurified antibodies to $56 \mathrm{kDa}$ SBP. Numerous longitudinally oriented immunoreactive fibers (arrows) can be seen in the lateral funiculus $(l f)$. $B$, Serial section exposed to antibodies to 5 -HT. The pattern of immunoreactivity is similar to that seen with antibodies to $56 \mathrm{kDa}$ SBP. Bars, $50 \mu \mathrm{m}$. 

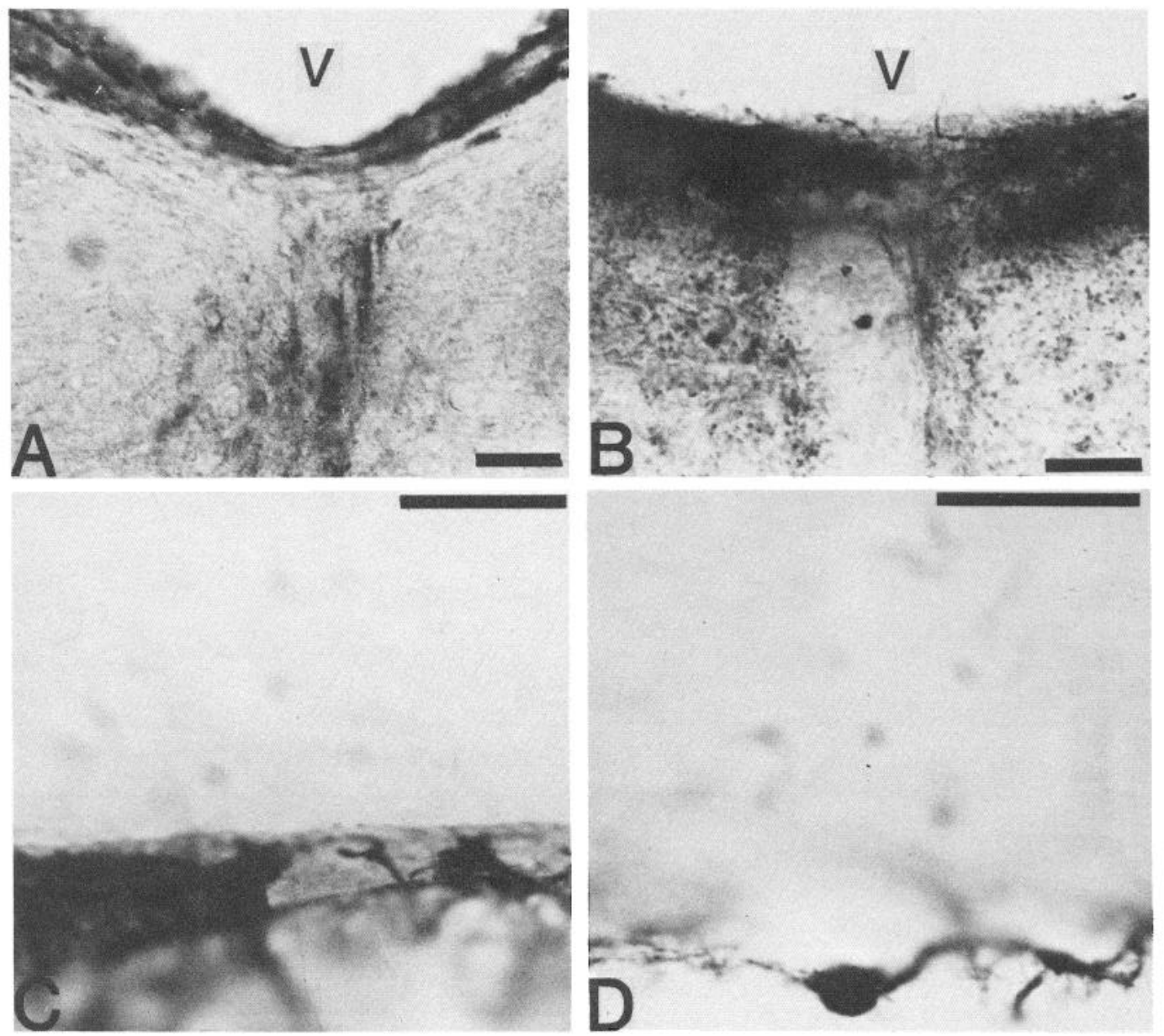

Figure 10. Single-label immunodetection. $A, B$, Supraependymal fibers form a dense plexus of fibers on the surface of the fourth ventricle ( $V$ ), which is immunostained both with antibodies to $56 \mathrm{kDa}$ SBP $[A]$ and with antibodies to $5-\mathrm{HT}[B]$. Both immune reagents also immunostain the neuropil in the central gray matter under the fourth ventricle. In $A$, antibodies to $56 \mathrm{kDa}$ SBP also label cells and fibers of the caudal tip of the nucleus raphe dorsalis, which is included in the section. $C, D$, Ventral surface of the caudal hypothalamus. Rare cell bodies and a plexus of fibers are immunostained both with antibodies to $56 \mathrm{kDa}$ SBP $[C]$ and with antibodies to $5-\mathrm{HT}[D]$. Fibers appear to extend into the meninges. Bars, $30 \mu \mathrm{m}$.

actin isoform restricted to cells with a single neurotransmitter. More compelling is the failure of anti-45 kDa SBP sera to react with actin and the failure of 3 different actin antibodies to recognize $45 \mathrm{kDa}$ SBP. Finally, it should be noted that the affinity of actin for 5-HT is much less than that of $45 \mathrm{kDa}$ SBP, and the optimal conditions for binding of 5-HT by the 2 molecules differ considerably (Small and Wurtman, 1984; Liu et al., 1985). It thus seems highly probable that SBP is not a form of actin.

No differences could be discerned in the patterns of 45 and $56 \mathrm{kDa}$ SBP immunoreactivities. Neither could be detected in cell bodies in the absence of colchicine, both accumulated in perikarya following administration of colchicine, and both were detected in terminals. The immunocytochemical data thus provide no support for the hypothesis that the 2 forms of SBP are differentially distributed within serotonergic neurons (Gershon et al., 1983). While the observations rule out the possibility that cell bodies contain only one form of SBP and terminals the other, immunocytochemistry does not provide a means with which the relative amount of $45 \mathrm{kDa}$ and $56 \mathrm{kDa}$ SBP in given regions of a neuron can be compared. It is likely that both forms of SBP are intravesicular and are present in all parts of serotonergic neurons; however, the possible existence of proximo- distal gradients in the relative abundance of the proteins, increasing in the case of $45 \mathrm{kDa} \mathrm{SBP}$, and decreasing for $56 \mathrm{kDa}$ $\mathrm{SBP}$, remains to be investigated.

The ease of immunocytochemical detection of $45 \mathrm{kDa}$ and $56 \mathrm{kDa}$ SBP in neurons and neurites of the brain and spinal cord bore no obvious relationship to the relative amounts of 5-HT in these structures. SBP immunoreactivity could be found even in those regions of the brain, such as the dorsomedial nucleus of the hypothalamus, substantia nigra, and arcuate nucleus (Fuxe and Ungerstedt, 1968; Kent and Sladek, 1978; Beaudet and Descarries, 1979; Frankfurt et al., 1981; Steinbusch et al., 1982), where 5-HT immunoreactivity cannot be detected in the absence of pharmacological loading by administration of L-tryptophan and a MAO inhibitor. This observation lends support to the idea that the neurons that contain 5-HT immunoreactivity following pharmacological elevation of their 5-HT concentration are really serotonergic and have properties that are similar to those of other serotonergic neurons, which may have more endogenous 5-HT and therefore be easier to demonstrate. The immunocytochemical localization of $45 \mathrm{kDa}$ or $56 \mathrm{kDa}$ SBP thus provides a sensitive and useful probe for serotonergic neurons. All of the known serotonergic cell groups 

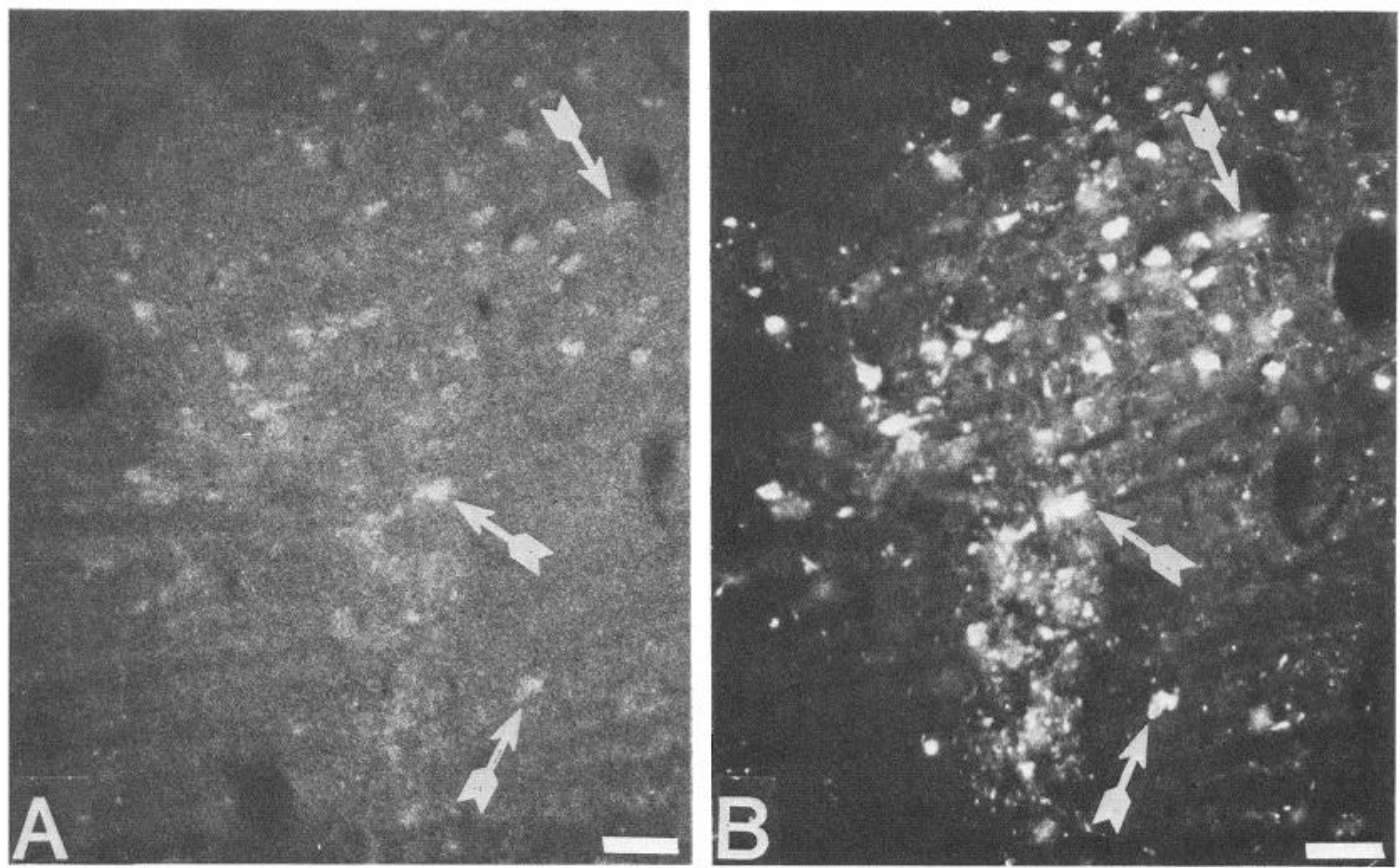

Figure 11. Nuclei raphe dorsalis and medianus. Simultaneous demonstration of immunoreactivity of $56 \mathrm{kDa}$ SBP $[A]$, visualized with a biotinylated secondary antibody and avidin-FITC, and 5-HT $[B]$, visualized with a TRITC-labeled secondary antibody. All structures found to be immunofluorescent following incubation with antibodies to $56 \mathrm{kDa}$ SBP are also immunostained by antibodies to 5-HT. The arrows point to the same cells, which are doubly labeled. Bars, $50 \mu \mathrm{m}$.

and terminal areas, including the supraependymal plexus, were found to be $\mathrm{SBP}^{+}$. In addition, 45 and $56 \mathrm{kDa}$ SBP immunoreactivities were also colocalized with that of 5-HT in small subpial cells on the ventral surface of the medulla and hypothalamus. The medullary neurons have been reported previously (Gorcs et al., 1985), but those of the hypothalamus have not. It is possible that the hypothalamic subpial serotonergic cells are those that have been described in the same location containing histidine decarboxylase (Reiner et al., 1987). The possible costorage of 5-HT and histamine, which has been re- ported in the rat's carotid body (Soinila et al., 1987), should thus be investigated in the CNS. The presence of serotonergic neurites in contact with cerebrospinal fluid (CSF) in the supraependymal plexus, in the area postrema, and in a subpial location on the ventral surface of the brain apparently projecting to the leptomeninges (Gorcs et al., 1985) is consistent with the possibility that 5-HT plays a humoral role in the CSF and/or that serotonergic neurons are influenced by humoral factors present in the CSF.

The role played by the 2 forms of SBP in the physiology of
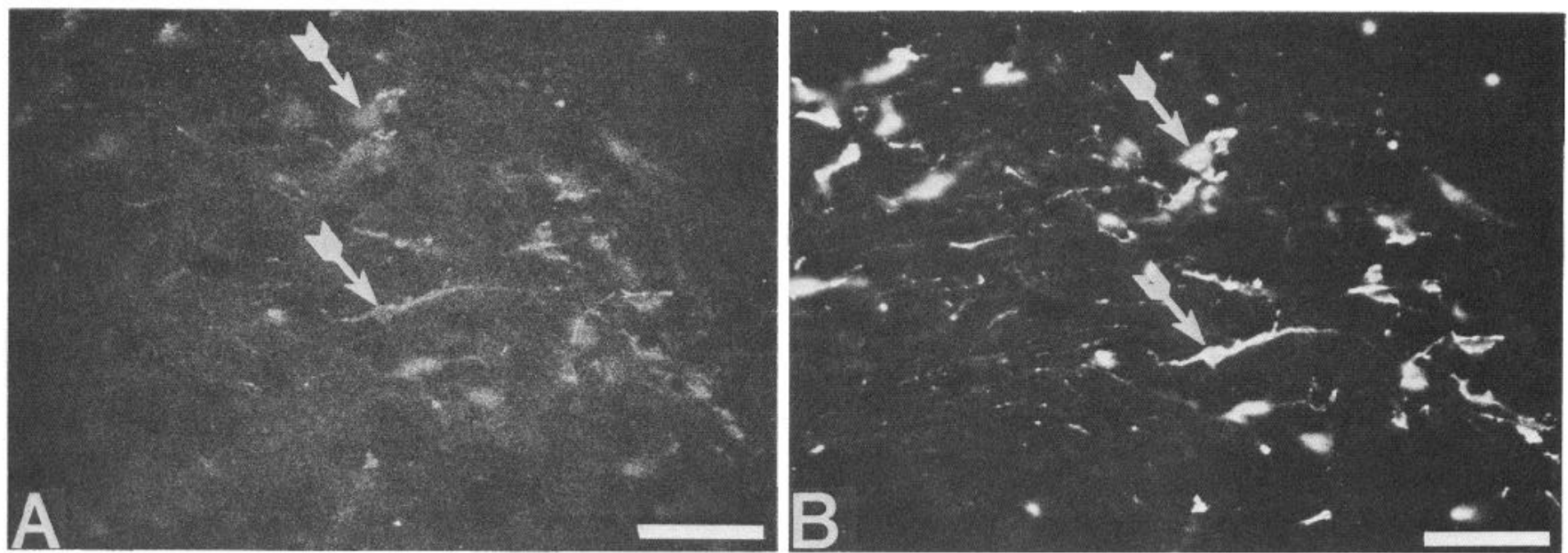

Figure 12. Group B9 of Dahlström and Fuxe (1964). A, Vibratome section exposed to affinity-purified antibodies to $45 \mathrm{kDa}$ SBP, in which sites of immunoreactivity are shown with avidin-FITC. A crescent-shaped cluster of neurons dorsal to the median lemniscus is immunoreactive. $B$, The same section has been exposed to antibodies to 5-HT, and sites of 5-HT immunoreactivity are visualized with a TRITC-labeled secondary antiserum. All structures found to be immunofluorescent following incubation with antibodies to $45 \mathrm{kDa}$ SBP $[A]$ are also immunostained by antibodies to 5-HT $[B]$. The arrows point to the same cells, which are doubly labeled. Bars, $50 \mu \mathrm{m}$. 

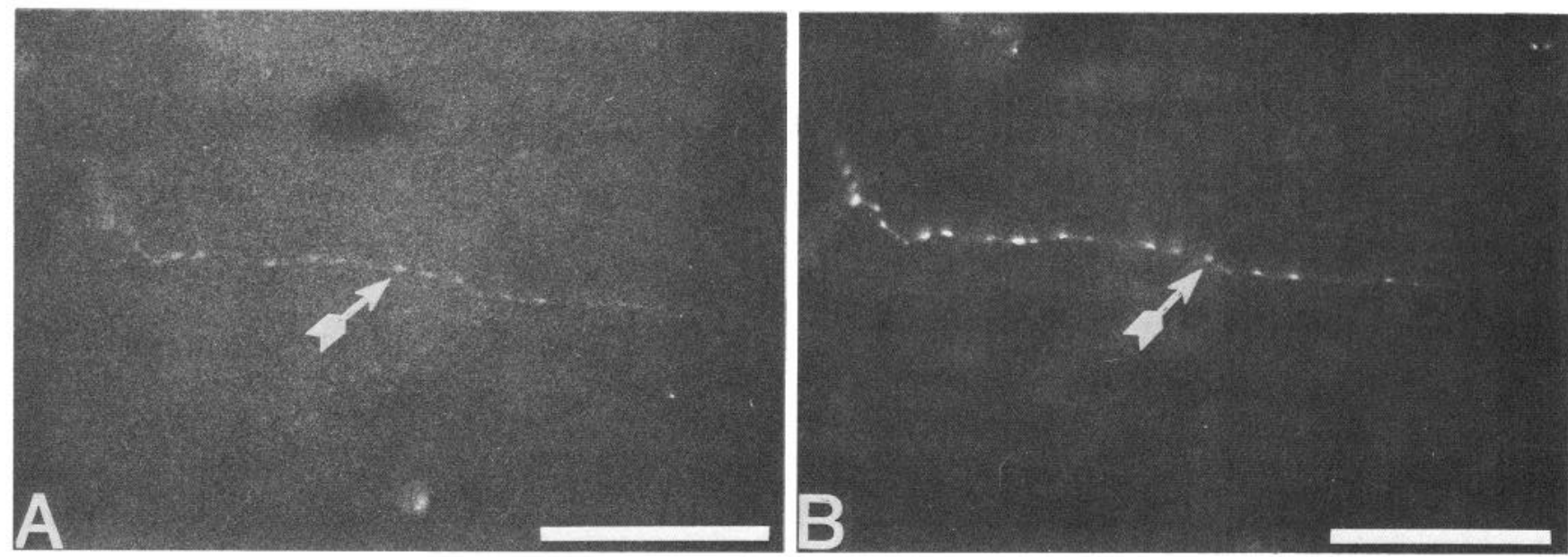

Figure 13. Lateral funiculus of the cervical spinal cord. Simultaneous demonstration of immunoreactivity of $45 \mathrm{kDa}$ SBP [A], visualized with a biotinylated secondary antibody and avidin-FITC, and of 5-HT $[B]$ visualized with a TRITC-labeled secondary antibody. All fibers found to be immunofluorescent following incubation with antibodies to $45 \mathrm{kDa}$ SBP are also immunostained by antibodies to 5-HT. The arrows point to the same beaded axons, which are doubly labeled. Bars, $50 \mu \mathrm{m}$.

serotonergic neurons remains to be determined. Whether or not a binding protein like SBP is present in other types of neuron also remains to be seen. It is possible that serotonergic neurons are unique in containing a protein that binds the transmitter intracellularly with high affinity; however, the serotonergic neuron may not be the only neuron that uses such a specific transmitter-binding protein. Other neurons may do so as well. If so, the SBP in serotonergic neurons may serve as a model for a more generally applicable mechanism of transmitter storage.

\section{References}

Adlersberg, M., K.-P. Liu, S. C. Hsiung, Y. Ehrlich, and H. Tamir (1987) $\mathrm{A} \mathrm{Ca}^{2+}$ dependent protein kinase activity associated with serotonin binding protein. J. Neurochem. 49: 1105-1115.

Barasch, J. M., H. Mackey, H. Tamir, E. A. Nunez, and M. D. Gershon (1987a) Induction of a neural phenotype in a serotonergic endocrine cell derived from the neural crest. J. Neurosci. 7: 2874-2883.

Barasch, J. M., H. Tamir, E. A. Nunez, and M. D. Gershon (1987b) Serotonin-storing secretory granules from thyroid parafollicular cells. J. Neurosci. 7: 4017-4033.

Beaudet, A., and L. Descarries (1979) Radiographic characterization of a serotonin-accumulating nerve cell group in adult rat hypothalamus. Brain Res. 160: 231-243.

Bernd, P., M. D. Gershon, E. A. Nunez, and H. Tamir (1981) Separation of dissociated thyroid follicular and parafollicular cells: Association of serotonin binding protein with parafollicular cells. J. Cell Biol. 88: 499-508.

Berneis, K. H., M. DaPrada, and A. Pletscher (1969) Physicochemical properties of 5-hydroxytryptamine organelles of blood platelets. In Agents and Actions, vol. 1, pp. 35-38, Birkhauser Verlag, Basel.

Costa, M., J. B. Furness, and I. J. Llewellyn-Smith (1987) Histochemistry of the enteric nervous system. In Physiology of the Gastrointestinal Tract, vol. 1, L. R. Johnson, J. Christensen, M. J. Jackson, E. D. Jacobson, and J. H. Walsh, eds., pp. 1-40, Raven, New York.

Dahlström, A., and K. Fuxe (1964) Evidence for the existence of monoamine-containing neurons in the central nervous system. I. Demonstration of monoamines in cell bodies of brain stem neurons. Acta Physiol. Scand. (Suppl.) 232: 1-55.

DaPrada, M., and A. Pletscher (1968) Isolated 5-hydroxytryptamine organelles of rabbit blood platelets: Physiological properties and druginduced changes. Br. J. Pharmacol. 34: 591-597.

DeJong, A. S. H., M. Van Kessel-Van Vark, and A. K. Raap (1985) Sensitivity of various visualization methods for peroxidase and alkaline phosphatase activity in immunoenzyme histochemistry. Histochem. J. 17: 1119-1130.
Frankfurt, M., J. M. Lauder, and E. C. Azmitia (1981) The immunocytochemical localization of serotonergic neurons in the rat hypothalamus. Neurosci. Lett. 24: 227-232.

Fuxe, K., and U. Ungerstedt (1968) Histochemical studies on the distribution of catecholamine and 5-hydroxytryptamine after intraventricular injections. Histochemie 13: 16-28.

Gershon, M. D., and H. Tamir (1981) Release of endogenous 5-hydroxytryptamine from resting and stimulated enteric neurons. Neuroscience 6: 2277-2286.

Gershon, M. D., K.-P. Liu, S. E. Karpiak, and H. Tamir (1983) Storage of serotonin in vivo as a complex with serotonin-binding protein in central and peripheral serotonergic neurons. J. Neurosci. 3: 19011911.

Gold, S., M. D. Gershon, and H. Tamir (1982) Comparison of serotonin binding protein of neurons and enterochromaffin cells. Soc. Neurosci. Abstr. 8: 408.

Gorcs, T. J., Z. Liposits, S. L. Palay, and V. Chan-Palay (1985) Serotonin neurons on the ventral brain surface. Proc. Natl. Acad. Sci. USA 82: 7449-7452.

Grafstein, B. (1977) Axonal transport: The intracellular traffic of the neuron. In Handbook in Physiology: The Nervous System, J. M. Brookhart, V. B. Mountcastle, E. R. Kandel, and S. R. Geiger, eds., pp. 691-717, American Physiological Society, Bethesda, MD.

Jonakait, J. M., H. Tamir, M. M. Rapport, and M. D. Gershon (1977) Detection of a soluble serotonin binding protein in mammalian myenteric plexus and other peripheral sites of serotonin storage. J. Neurochem. 28: 277-284.

Jonakait, J. M., H. Tamir, A. R. Gintzler, and M. D. Gershon (1979) Release of serotonin and its binding protein by enteric neurons. Brain Res. 174: 55-69.

Kent, D. L., and J. R. Sladek (1978) Histochemical, pharmacological and microspectrofluorometric analysis of new sites of serotonin localization in the rat hypothalamus. J. Comp. Neurol. 180: 221-236.

Lazarides, E., and U. Lindberg (1974) Actin is the naturally occurring inhibitor of deoxyribonuclease I. Proc. Natl. Acad. Sci. USA 71: 4742-4746.

Liu, K.-P., M. D. Gershon, and H. Tamir (1985) Identification, purification, and characterization of two forms of serotonin binding protein from rat brain. J. Neurochem. 44: 1289-1301.

Polak, J. M., G. E. Pearse, C. LeLievre, J. Fontaine, and N. M. Le Douarin (1974) Immunocytochemical confirmation of the neural crest origin of avian calcitonin-producing cells. Histochemistry 40: 209-214.

Ponder, B. A., and M. M. Wilkinson (1981) Inhibition of endogenous tissue alkaline phosphatase with the use of alkaline phosphatase conjugates in immunohistochemistry. J. Histochem. Cytochem. 29: 981984.

Reiner, P. B., K. Semba, T. Watanabe, and H. Wada (1987) En bloc 
immunohistochemistry reveals extensive distribution of histidine decarboxylase-immunoreactive neurons on the ventral surface of the rat hypothalamus. Neurosci. Lett. 77: 137-142.

Richards, G. (1983) Ultrastructural visualization of biogenic monoamines. In Handbook of Chemical Neuroanatomy, vol. 1, A. Björklund and T. Hökfelt, eds., pp. 122-146, Elsevier, New York.

Rothman, T. P., D. Sherman, P. Cochard, and M. D. Gershon (1986) Development of the monoaminergic innervation of the avian gut: Transient and permanent expression of phenotypic markers. Dev. Biol. 116: 357-380.

Small, D. H., and R. J. Wurtman (1984) Serotonin binds specifically and saturably to an actin-like protein isolated from rat brain synaptosomes. Proc. Natl. Acad. Sci. USA 81: 959-963.

Soinila, S., O. Happola, H. Steinbusch, T. Watanabe, and P. Panula (1987) Immunohistochemical demonstration of 5-hydroxytryptamine, histamine and histidine decarboxylase in the rat carotid body. J. Neurochem. (Suppl.) 48: 84.

Steinbusch, H. W. M. (1981) Distribution of serotonin-immunoreactivity in the central nervous system of the rat. Cell bodies and terminals. Neuroscience 4: 557-618.

Steinbusch, H. W. M., A. A. J. Verhofstad, H. W. J. Joosten, and M. Goldstein (1982) Serotonin-immunoreactive cell bodies in the nucleus dorsomedialis hypothalami, in the substantia nigra and in the area tegmentalis ventralis of Tsai: Observations after pharmacological manipulations in the rat. In Cytochemical Methods in Neuroanatomy, S. Palay and V. Chan-Palay, eds., pp. 407-421, Liss, New York.

Sternberger, L. A. (1979) The unlabeled antibody peroxidase-antiperoxidase (PAP) method. In Immunocytochemistry, L. Sternberger, ed., pp. 104-169, Wiley, New York.

Sternberger, L. A., and S. A. Joseph (1979) The unlabeled antibody method: Contrasting color staining of paired pituitary hormones withnut antibody removal. J. Histochem. Cytochem. 27: 1424-1429.

Tamir, H., and M. D. Gershon (1979) Storage of serotonin and serotonin binding protein in synaptic vesicles. J. Neurochem. 33: 35-44.

Tamir, H., and Y. L. Huang (1974) Binding of serotonin to soluble protein from synaptosomes. Life Sci. 14: 83-93.

Tamir, H., and M. J. Kuhar (1975) Association of serotonin-binding protein with projections of the midbrain raphe nuclei. Brain Res. 83 : $169-172$.

Tamir, H., A. Klein, and M. M. Rapport (1976) Serotonin binding protein: Enhancement of binding by $\mathrm{Fe}^{+2}$ and inhibition of binding by drugs. J. Neurochem. 26: $871-878$.

Tamir, H., T. C. Theoharides, M. D. Gershon, and P. W. Askenase (1982) Serotonin storage pools in basophil leukemia and mast cells: Characterization of two types of serotonin binding protein and radioautographic analysis of the intracellular distribution of $\left({ }^{3} \mathrm{H}\right)$ serotonin. J. Cell Biol. 93: 638-647.

Tamir, H., W. J. Kupsky, Y. L. Huang, and M. D. Gershon (1983) Serotonin binding glycoprotein of rat platelets. J. Cell Sci. 62: 439 458.

Tamir, H., R. F. Payette, Y. L. Huang, K. P. Liu, and M. D. Gershon (1985) Human serotonectin: A blood glycoprotein that binds serotonin and is associated with platelets and white blood cells. J. Cell Sci. 73: 187-206

Towbin, H., T. Staehelin, and G. Gordon (1979) Electrophoretic transfer of proteins from polyacrylamide gels to nitrocellulose sheets: Procedure and some applications. Proc. Natl. Acad. Sci. USA 76:43504354.

Winkler, H., and E. Westhead (1980) The molecular organization of adrenal chromaffin granules. Neuroscience 5: 1803-1823. 